\title{
HUBUNGAN ANTARA DUKUNGAN SOSIAL SUAMI DENGAN KONFLIK PERAN GANDA PADA GURU WANITA DI KABUPATEN HALMAHERA BARAT
}

\author{
Evani Julianty \\ Fakultas Psikologi Universitas Kristen Satya Wacana Salatiga \\ evanijulianty11@gmail.com \\ Berta Esti Ari Prasetya \\ Staf Pengajar Fakultas Psikologi Universitas Kristen Satya Wacana Salatiga \\ bertaprasetya@gmail.com
}

\begin{abstract}
Abstrak
Memiliki peran ganda membuat wanita berpeluang besar mengalami konflik. Dukungan sosial suami diharapkan menjadi salah satu faktor yang dapat mengurangi atau bahkan mengatasi konflik peran ganda. Penelitian ini bertujuan mengetahui korelasi negatif antara dukungan sosial suami dengan konflik peran ganda. Metode pengumpulan data menggunakan metode skala, yang terdiri dari skala dukungan sosial suami yang disusun oleh peneliti berdasarkan teori yang dikemukakan oleh James S. House (1987) $(\alpha=0.878)$ dan skala konflik peran ganda yang diadaptasi dari skala konflik peran ganda yang disusun oleh Carlson, Kacmar dan Williams (2000) $(\alpha=0,809)$. Subjek penelitian adalah guru wanita SMA dan SMK di kabupaten Halmahera Barat. Teknik pengambilan sampel menggunakan teknik accidental sampling dengan total subjek 71 orang. Hasil uji penelitian ini menunjukan adanya hubungan negatif yang tidak signifikan antara dukungan sosial suami dengan konflik peran ganda $(r=-$ $0,184 \mathrm{p}<0,005)$.

Kata kunci: konflik peran ganda, dukungan sosial suami, guru wanita
\end{abstract}

\begin{abstract}
Having multiples roles to may lead to women to have a work-family conflict. Husband's support expected to be a factor that can reduce or even resolve the work-family conflict. This study is a quantitative research aimsed to find a negative correlation between husband's support with work-family conflict. There were two scales used for data collection, which were scale of husband's support compiled by researchers based on the theory by James S. House (1987) ( $\alpha=$ 0.878 ) and scale of work-family conflict adapted from work-family conflict scale by Carlson, Kacmar and Williams (2000) $(\alpha=0.809)$. The research subjects were female teachers of senior high school and vocational high school in West Halmahera. The sampling technique used was accidental sampling with total of 71 subjects. That there is a negative correlation but not significant between husband's support and work-family conflict.
\end{abstract}

Keywords: work-family conflict, husband support, female teachers 


\section{PENDAHULUAN}

Dalam era saat ini, wanita yang berperan sebagai orang tua dan pekerja di luar rumah tidak lagi menjadi hal yang langka akan tetapi sudah sangat umum. Secara khusus di Indonesia pada tahun 2011, wanita yang bekerja dan berstatus menikah yang berumur 15 tahun ke atas berjumlah sebesar 71,52 persen (Profil Perempuan Indonesia, 2012). Hal ini menunjukkan bahwa eksistensi dari wanita Indonesia dalam pekerjaan sendiri telah diakui di berbagai bidang.

Khususnya dalam bidang pendidikan, guru adalah profesi yang cukup diminati atau ditekuni oleh wanita-wanita di Indonesia. Mulai dari tingkat sekolah dasar sampai pada tingkat sekolah menengah atas dan kejuruan memiliki guru wanita. Di provinsi Maluku Utara misalnya, total jumlah guru wanita sekolah dasar sampai sekolah menengah atas dan kejuruan pada tahun 2012 sebesar 9564 orang, bahkan guru wanita pada setiap tingkatnya lebih banyak dibandingkan guru pria kecuali tingkat kejuruan (http://www.data.go.id/dataset/guru-berdasarkan-gender).

Meski kebanyakan dari wanita memilih untuk menjadi guru, profesi tersebut memiliki beban kerja yang cukup sulit. Faktor yang mempengaruhi beban kerja guru, diantaranya prosedur yang lebih formal dalam melakukan pekerjaan, membuat para guru kesulitan dalam merencanakan pekerjaan mereka sendiri. Guru juga bertanggung jawab untuk menambah pengetahuan dan perkembangan sosial-emosional murid mereka, dengan demikian hal itu meningkatkan tuntutan profesi guru (Peeters \& Rutte, 2005).

Dalam penelitian ini, penulis memfokuskan pada pembahasan yang terkait dengan konflik peran ganda pada Guru Wanita di Kabupaten Halmahera Barat. Konflik peran ganda juga didefinisikan sebagai suatu bentuk konflik antar peran dimana tekanan peran dari pekerjaan dan keluarga saling bertentangan dalam beberapa hal tertentu (Greenhaus \& Beutell, 1985). Terdapat tiga bentuk konflik peran ganda yang dikemukakan oleh Greenhaus dan Beutell (1985) yaitu; (a) konflik berdasar waktu (time-based conflict), dimana waktu yang dihabiskan untuk satu peran membuat individu sulit untuk berpartisipasi dalam perannya yang lain. (b) konflik berdasar regangan (strain-based conflict), hal ini konsisten dengan kelelahan atau dimensi iritabilitas, dimana kelelahan atau iritabilitas dalam satu peran mempengaruhi kinerja individu dalam peran lain. Dengan kata lain, peran tidak kompatibel karena kelelahan atau iritabiltias yang ditimbulkan oleh salah satu peran mengakibatkan kesulitan dalam memenuhi tuntutan peran yang lain. (c) konflik berdasar perilaku (behavior based conflict), dimana pola perilaku individu dalam satu peran tidak sesuai dengan harapan pada peran lainnya.

Konsisten dengan ketiga bentuk konflik peran ganda tersebut, Gutek dan Larwood (1991) dalam Carslon, Kacmar dan Williams (2000), berpendapat bahwa masing-masing dari tiga bentuk konflik peran ganda memiliki dua arah: (a) konflik karena pekerjaan mengganggu keluarga (Work 
Interference with Family) (WIF), (b) konflik karena keluarga mengganggu pekerjaan (Family Interference with Work) (FIW). Kemudian, ketiga bentuk tersebut digabungkan dengan dua arah, menghasilkan enam dimensi konflik peran ganda yaitu, a) WIF berbasis waktu, b) waktu berbasis FIW, c) WIF berbasis regangan, d) regangan berbasis FIW, e) perilaku berbasis FIW, f) WIF berbasis perilaku.

Berdasarkan hasil wawancara yang dilakukan pada tanggal 15 Februari 2016 kepada salah satu guru wanita di SMA Negeri 1 Halmahera Barat, dijelaskan bahwa ada fenomenafenomena yang terkait dengan konflik peran ganda yaitu guru wanita yang mempunyai tanggung jawab di sekolah sering sekali tidak selesai dan harus di bawa pulang ke rumah. Tanggung jawab tersebut antara lain memeriksa pekerjaan rumah siswa, ulangan harian, ulangan tengah dan akhir semester, menyusun perangkat pembelajaran, dan menyiapkan materi (belajar kembali) untuk bahan ajar siswa. Ditambah lagi tanggung jawab yang dibebankan oleh kepala sekolah seperti mengurus proyek pembangunan sekolah, wali kelas, dan penanggung jawab acara-acara yang akan diselenggarakan oleh sekolah maupun OSIS. Padahal di rumah sendiri memiliki tanggung jawab lain seperti mengurus anak-anak, suami dan bahkan pekerja kebun.

Wanita yang berprofesi sebagai guru sekaligus istri dan ibu memegang tanggung jawab yang besar dalam kehidupan rumah tangga. Dikarenakan wanita merupakan pelaku utama yang berperan dalam pelayanan yang dilakukan di rumah, yaitu mengurus rumah dan anak-anak (Chopur, 2011).

Dengan berperan sebagai guru sekaligus istri dan ibu, wanita menanggung beban kerja yang tidak jarang menimbulkan tekanan pada saat berusaha memenuhi tuntutan peran dalam pekerjaan dan rumah tangga. Hal tersebut memungkinkan berprofesi sebagai guru dapat mengalami stres kerja yang tinggi (Nikmah \& Mahnum, 2011; dalam Nurmayanti, Thoyib, Noermijanti \& Irawanto, 2014). Bahkan, beberapa peneliti juga menyatakan bahwa profesi guru telah diakui secara internasional sebagai salah satu profesi yang memiliki tingkat stres tertinggi (Hakanen, Bakker \& Schaufeli, 2006; dalam Wafula, 2010).

Ketidakmampuan untuk mengatasi dan menyeimbangkan peran ganda tersebut dapat berpotensi menimbulkan konflik diantara kedua peran atau konflik pekerjaan-keluarga (WorkFamily Conflict). Sebagaimana disebutkan oleh Gutek, Searle dan Klepa (1991) peran ganda yang dialami wanita mempunyai kesulitan dan juga kegagalan pemenuhan tuntutan dari salah satu peran baik sebagai ibu rumah tangga, individu, wanita bekerja dan warga masyarakat tersebut akan menimbulkan konflik. Pada level individu, konflik peran ganda memiliki kaitan yang cukup besar dengan masalah stres, hipertensi, dan secara keseluruhan rendahnya kesejahteraan fisik dan psikologis (Frone dkk, 1997; dalam Amazue, 2013). Pada tingkat 
organisasi, konflik peran ganda memiliki hubungan dengan peningkatan absensi, berkurangnya involvement career, dan penurunan kepuasan kerja (Greenhaus et al, 2001; Netemeyer, 1996; dalam Amazue, 2013).

Sementara itu, konflik peran ganda yang dialami para wanita, menurut hasil penelitian Ahmad (1997) dapat berkurang apabila mereka mendapatkan dukungan sosial dari empat sumber dukungan yaitu atasan, rekan kerja, suami dan teman-teman atau kerabat. Sarafino (1994) menggambarkan dukungan sosial sebagai suatu kenyamanan, perhatian, penghargaan ataupun bantuan yang diterima individu dari orang lain mapun kelompok. Definisi dukungan sosial lainnya, menurut Schwarzer dan Knoll (2007) dukungan sosial dapat dikatakan sebagai sumber daya yang berasal dari orang lain, yang bertujuan memberi bantuan, atau sebagai pertukaran sumber daya. Secara khusus, dukungan sosial suami adalah dorongan untuk memotivasi istri, baik secara moral maupun material (Bobak, 2002; dalam Rahmadita, 2013).

Adapun House (dalam Sarafino, 1994) telah mengklasifikasikan empat aspek perilaku dukungan sosial yaitu; (a) dukungan emosional, yang adalah pemberian empati, kepedulian, cinta, kepercayaan, perhatian dan mendengarkan, (b) dukungan instrumental, yaitu menyediakan bantuan dalam bentuk barang, uang, tenaga, waktu atau bantuan langsung, (c) dukungan informasi, yaitu memberikan nasehat, saran, arahan atau informasi yang akan digunakan dalam mengatasi masalah pribadi dan lingkungan, (d) dukungan penilaian, yaitu memberikan penegasan, umpan balik, perbandingan sosial, dan evaluasi diri.

Dukungan sosial emosional yang diberikan suami kepada istri misalnya berupa mendengarkan cerita istri, mengucapkan kata-kata cinta, dapat meningkatkan rasa percaya diri istri baik di rumah maupun di tempat kerja (Parasuraman, Purohit, \& Godshalk, 1996; dalam Aycan \& Eskin, 2005). Hal ini membuat istri tidak mudah mengalami stres yang merupakan dampak dari konflik peran ganda. Dibuktikan dalam penelitian Jex dan Bliese (1999), bahwa individu dengan kepercayaan diri yang tinggi lebih mampu mengembangkan cara mengatasi stres yang efektif dibanding individu dengan tingkat kepercayaan diri rendah.

Selain itu, dukungan sosial instrumental yang diberikan suami untuk membantu tugas istri di rumah misalnya dengan mencuci piring, bergantian menjaga anak di waktu anak sakit, dan lain sebagainya, sangat jelas meringankan beban tanggung jawab keluarga dan memungkinkan istri memberikan waktu yang cukup untuk pekerjaannya (Parasuraman et al., 1996; dalam Aycan et al., 2005), maka kemungkinan timbulnya konflik karena keluarga menganggu pekerjaan akan sangat kecil.

Kemudian, suami yang memberikan nasehat, saran dan evaluasi untuk istri guna menjadi bahan pertimbangan istri dalam mengambil keputusan adalah bentuk dukungan sosial informasi 
dan penilaian. Hal ini dapat memberi dampak, istri menjadi memiliki sarana pilihan dalam pengambilan keputusan lebih banyak dibanding dengan yang tidak mendapatkan dukungan informasi dari suami. Dengan banyaknya pilihan, istri tidak harus mencurahkan waktu, pikiran maupun tenaga lebih banyak untuk memikirkan keputusan yang harus diambil, sehingga kemungkinan adanya konflik karena pekerjaan mengganggu keluarga atau sebaliknya akan semakin berkurang.

Selanjutnya, dalam penelitian Murtinigrum (2005) dengan responden guru kelas 3 SMP Negeri di Kendal sebanyak 100 orang, menunjukkan hasil dukungan sosial tertinggi berasal dari pasangan hidup dan keluarga, dukungan sosial yang berasal dari keluarga akan mengurangi konflik peran ganda, meningkatkan kepuasan kerja, dan mengurangi masalah kesehatan yang berhubungan dengan stres kerja.

Penelitian dengan responden guru dan dosen tetap pada Universitas Katolik Widya Mandala dan SMA St. Bonaventura Kota Madiun dengan jumlah sampai 38 orang, memberikan hasil adanya hubungan negatif yang signifikan antara dukungan sosial yang diberikan oleh suami dengan konflik peran ganda (Apollo \& Cahyadi, 2012)

Selvarajan, Cloninger dan Singh (2013) dalam penelitian mereka dengan 435 karyawan full-time dari berbagai organisasi yang terdaftar dalam program MBA eksekutif di Southwestern University menyimpulkan bahwa dukungan emosional yang diberikan oleh pasangan/mitra memiliki efek menguntungkan dalam memajukan keseluruhan kesejahteraan emosional dari karyawan yang telah berusaha menangani konflik yang berasal dari dua bagian penting yaitu pekerjaan dan keluarga.

Dukungan sosial dari pasangan hidup atau suami, dalam beberapa penelitian merupakan faktor yang berperan dalam mengurangi konflik peran ganda, bahkan mempengaruhi faktor lain terhadap wanita bekerja sekaligus berperan sebagai istri dan ibu. Hal ini membuat peneliti tertarik untuk meneliti apakah ada hubungan yang signifikan antara dukungan sosial suami dengan konflik peran ganda pada guru wanita di kabupaten Halmahera Barat.

\section{HIPOTESIS}

Adanya hubungan negatif yang signifikan antara dukungan sosial suami dengan konflik peran ganda pada guru wanita di kabupaten Halmahera Barat.

\section{METODE PENELITIAN}

\section{Variabel Penelitian}

Variabel terikat

: Konflik peran ganda

Variabel bebas

: Dukungan sosial suami 


\section{Partisipan}

Penelitian mengambil populasi dan sampel guru wanita di Sekolah Menengah Atas (SMA) dan Sekolah Menengah Kejuruan (SMK) di Kabupaten Halmera Barat. Dengan kriteria sebagai berikut: (a) guru wanita dengan minimal pengalaman kerja 6 bulan, (b) aktif sebagai seorang guru dalam lembaga pendidikan (SD, SMP, SMA atau SMK) atau belum pensiun, (c) tinggal bersama suami dan anak (tidak dalam keluarga besar), (d) memiliki minimal 1 orang anak usia 0 sampai 17 tahun atau dalam usia sekolah (SD, SMP, SMA atau SMK). Teknik pengambilan sampel yang digunakan dalam penelitian ini adalah accidental sampling dan sampel yang berhasil ditemui berjumlah 71 orang. Etnis, agama, tingkat pendidikan, pekerjaan suami, dan usia pernikahan diabaikan dalam penelitian ini.

\section{Metode Pengumpulan Data}

Penelitian ini merupakan penelitian kuantitatif. Peneliti melakukan pengumpulan data pada guru wanita SMA dan SMK di kabupaten Halmahera Barat dengan kriteria yang telah disebutkan sebelumnya, dengan cara memberikan kuesioner untuk mengukur konflik peran ganda yang diadaptasi dari Work-Family Conflict Scale source Carlson, Kacmar and Williams (2000) dan pengukuran dukungan sosial suami menggunakan alat ukur atau skala yang disusun oleh peneliti.

\section{Instrumen Alat Ukur}

a. Work-Family Conflict Scale source Carlson, Kacmar and Williams (2000)

Alat ukur ini disusun oleh Carlson, Kacmar dan Williams (2000) untuk mengukur enam dimensi dalam konflik peran ganda. Alat ukur ini menggunakan pengskalaan model Likert dengan empat pilihan jawaban yaitu; Sangat Setuju (SS) dengan skor $=4$, Setuju (S) dengan skor $=3$, Tidak Setuju (TS) dengan skor $=2$, Sangat Tidak Setuju (STS) dengan skor $=1$. Terdapat 18 item dalam alat ukur ini dan untuk masing-masing dimensi terdapat 3 item. Pada uji validitas dari 18 item terdapat 3 item gugur dan tersisa 15 item yang bergerak dari 0,36-0,706. Adapun uji reliabilitas diperoleh $\alpha=0,809$.

b. Skala Dukungan Sosial Suami

Untuk mengukur dukungan sosial suami, peneliti secara mandiri menyusun kuesioner yang berdasar pada definisi yang dikemukakan oleh Sarafino (1994) dan aspek-aspek dari dukungan sosial yang dikemukakan oleh House (dalam Sarafino, 1994). Alat ukur ini menggunakan pengskalaan model Likert dengan empat pilihan jawaban yaitu; Sangat Setuju (SS) dengan skor $=4$, Setuju (S) dengan skor $=3$, Tidak Setuju (TS) dengan skor $=2$, Sangat Tidak Setuju (STS) dengan skor $=1$. Kuesioner ini terdiri dari 34 item, yang dibagi menjadi 17 
item favorable dan 17 item unfavorable. Pada uji validitas dari 34 item terdapat 2 item gugur dan tersisa 32 item yang bergerak dari 0,299-0,661. Adapun uji reliabilitas di peroleh $\alpha=0,878$.

\section{Teknik Analisis Data}

Penghitungan penelitian ini menggunakan bantuan program statistik komputer IBM SPSS ver. 21.00. Untuk menguji validitas item pada penelitian ini menggunakan Pearson's Product Moment (Azwar, 2009). Sedangkan untuk menguji reliabilitas pada penelitian ini menggunakan Cronbach Alpha. Pengujian normalitas pada penelitian ini menggunakan Kolmogorov-Smirnov, untuk uji linearitas digunakan ANOVA table of linearity, sedangkan pengujian hipotesisnya dan korelasi antara dimensi konflik peran ganda dengan dukungan sosial suami menggunakan Pearson's Product Moment.

\section{HASIL DAN PEMBAHASAN}

\section{A. Hasil Penelitian}

\section{Analisis Deskripstif}

Berikut adalah kategorisasi deskriptif dari hasil perhitungan variabel konflik peran ganda dan variabel dukungan sosial suami.

a. Variabel Konflik Peran Ganda

Tabel 1.1 Kategorisasi Konflik Peran Ganda

\begin{tabular}{|c|c|c|c|c|}
\hline Interval & Kategorisasi & Mean & $\mathbf{N}$ & Presentase \\
\hline $46 \leq x \leq 60$ & Tinggi & \multirow{3}{*}{33,55} & 0 & $0 \%$ \\
\hline $31 \leq x \leq 45$ & Sedang & & 52 & $36,92 \%$ \\
\hline $15 \leq x \leq 30$ & Rendah & & 19 & $13,49 \%$ \\
\hline \multicolumn{3}{|l|}{ Jumlah } & 71 & $50,41 \%$ \\
\hline
\end{tabular}

Berdasarkan tabel 1.1, diketahui guru wanita pada tingkat SMA \& SMK di kabupaten Halmahera Barat dengan kriteria yang telah ditentukan, terdapat 19 orang (13,49\%) dengan konflik peran ganda pada kategori rendah, 52 orang $(36,92 \%)$ pada kategori sedang dan tidak ada $(0 \%)$ pada kategori tinggi. Mean yang diperoleh adalah 33,55. Berdasarkan hasil kategori diatas, dapat disimpulkan bahwa sebagian besar guru wanita pada tingkat SMA \& SMK di kabupaten Halmahera Barat dengan kriteria yang telah ditentukan cenderung mengalami konflik peran ganda pada kategori sedang dengan rentang skala $31 \leq x \leq 45$. 
b. Variabel Dukungan Sosial Suami

Berdasarkan tabel 1.2 , diketahui terdapat 44 orang $(31,24 \%)$ guru wanita pada tingkat SMA \& SMK di kabupaten Halmahera Barat dengan kriteria yang telah ditentukan, mendapatkan dukungan sosial suami yang tergolong tinggi, 26 orang (18,46\%) tergolong sedang dan 1 orang $(0,71 \%)$ tergolong rendah. Mean yang diperoleh adalah 98,49 . Berdasarkan hasil kategori diatas, dapat disimpulkan bahwa sebagian guru wanita pada tingkat SMA \& SMK di kabupaten Halmahera Barat dengan kriteria yang telah ditentukan cenderung mendapatkan dukungan sosial suami pada tingkat tinggi dengan rentang skala $97 \leq x \leq 128$.

\section{Tabel 1.2 Kategorisasi Dukungan Sosial Suami}

\begin{tabular}{|l|l|l|l|l|}
\hline Interval & Kategorisasi & Mean & $\mathbf{N}$ & Presentase \\
\hline $\mathbf{9 7} \leq \mathbf{x} \leq \mathbf{1 2 8}$ & Tinggi & \multirow{2}{*}{$\mathbf{9 8 , 4 9}$} & $\mathbf{4 4}$ & $\mathbf{3 1 , 2 4 \%}$ \\
\hline $\mathbf{6 5} \leq \mathrm{x} \leq \mathbf{9 6}$ & Sedang & & $\mathbf{2 6}$ & $18,46 \%$ \\
\hline $32 \leq \mathrm{x} \leq 64$ & Rendah & & 1 & $0,71 \%$ \\
\hline \multicolumn{2}{|l|}{ Jumlah } & & 71 & $50,41 \%$ \\
\hline
\end{tabular}

\section{Uji Asumsi}

a. Uji Normalitas

One-Sample Kolmogorov-Smirnov Test

\begin{tabular}{|ll|l|l|}
\hline & & $\begin{array}{l}\text { DUKUNGAN } \\
\text { SOSIAL SUAMI }\end{array}$ & $\begin{array}{l}\text { KONFLIK } \\
\text { PERAN } \\
\text { GANDA }\end{array}$ \\
\hline$N$ & & 71 & 71 \\
Normal Parameters ${ }^{a, b}$ & Mean & 98.4930 & 33.5493 \\
& Std. Deviation & 9.78026 & 5.16800 \\
& Absolute & .140 & .118 \\
Most Extreme Differences & Positive & .121 & .068 \\
& Negative & -.140 & -.118 \\
Kolmogorov-Smirnov Z & & 1.179 & .991 \\
Asymp. Sig. (2-tailed) & & .124 & .280 \\
\hline
\end{tabular}

Berdasarkan hasil uji normalitas diperoleh nilai Kolmogorov Smirnov untuk variabel konflik peran ganda sebesar 0,991 > 0,05 dan untuk variabel konflik peran ganda sebesar 1,179>0,05. Maka dapat disimpulkan bahwa kedua variabel berdistribusi normal.

b. Uji Linearitas 
Dari hasil uji linearitas diperoleh nilai $F$ beda sebesar 0,815 dengan signifikansi 0,712 > 0,05 yang menunjukkan terdapat hubungan linear antara dukungan sosial suami dengan konflik peran ganda. Hasil uji linieritas dapat dilihat pada tabel berikut ini :

\begin{tabular}{|c|c|c|c|c|c|c|c|}
\hline & & & Sum of Squares & df & Mean Square & $\mathrm{F}$ & Sig. \\
\hline \multirow{5}{*}{$\begin{array}{l}\text { Konflik peran } \\
\text { ganda * } \\
\text { Dukungan Sosial } \\
\text { Suami }\end{array}$} & \multirow{3}{*}{$\begin{array}{l}\text { Between } \\
\text { Groups }\end{array}$} & (Combined) & 709.311 & 29 & 24.459 & \multirow{3}{*}{$\begin{array}{l}.864 \\
2.245 \\
.815\end{array}$} & \multirow{3}{*}{$\begin{array}{l}.656 \\
.142 \\
.712\end{array}$} \\
\hline & & Linearity & 63.533 & 1 & 63.533 & & \\
\hline & & $\begin{array}{l}\text { Deviation from } \\
\text { Linearity }\end{array}$ & 645.778 & 28 & 23.064 & & \\
\hline & \multicolumn{2}{|c|}{ Within Groups } & 1160.267 & 41 & 28.299 & & \\
\hline & \multicolumn{2}{|c|}{ Total } & 1869.577 & 70 & & & \\
\hline
\end{tabular}

c. Analisis Korelasi

Correlations

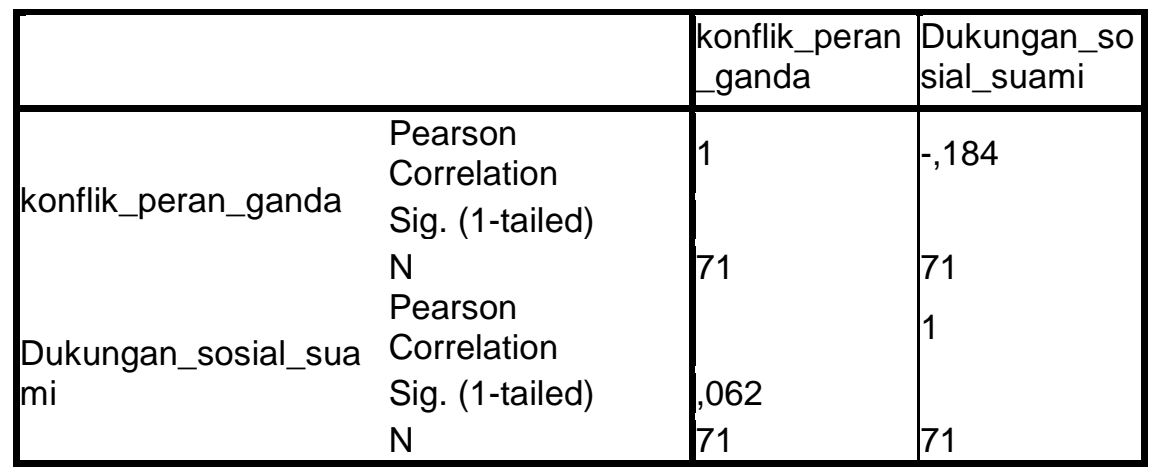

Hasil korelasi diperoleh koefesien korelasi antara Dukungan Sosial Suami dan Konflik Peran Ganda sebesar -0,184 dengan signifikansi 0,062 ( $p>0.05$ ). Hal ini menunjukkan bahwa ada hubungan negatif yang tidak signifikan antara Dukungan Sosial Suami dengan Konflik Peran Ganda.

\section{B. Pembahasan}

Hasil perhitungan dengan menggunakan SPSS dengan uji korelasi Pearson Product Moment dengan $r=-0,184$ dengan sig (one tailed) 0,062 ( $p>0.05$ ), hal ini menunjukkan bahwa ada hubungan negatif yang tidak signifikan antara dukungan sosial suami dengan konflik peran ganda pada guru wanita. Hasil penelitian ini tidak mendukung hipotesis awal yang menyatakan bahwa ada hubungan negatif yang signifikan antara dukungan sosial suami dengan konflik peran ganda pada guru wanita. Hasil penelitian ini bertentangan dengan hasil penelitian Apollo dan Cahyadi (2012) bahwa ada hubungan negatif yang signifikan antara dukungan sosial suami dengan konflik peran ganda. 
Hasil penelitian yang tidak mendukung hipotesis awal, dapat berarti tidak ada jaminan bahwa dukungan sosial yang diberikan oleh suami dapat menurunkan atau mengatasi konflik peran ganda. Seperti budaya masyarakat di Maluku, baik wanita yang tidak bekerja dan wanita yang bekerja harus bisa melakukan pekerjaan-pekerjaan rumah tangga seperti penyediaan pangan, mengurus anak, kesehatan anggota keluarga dan hal-hal rutin yang dilakukan dalam rumah tangga. Dalam penelitian Far Far (2012) di kabupaten Maluku Tengah, meskipun ada kerjasama antara suami dan istri dalam melakukan pekerjaan rumah tangga, istri atau wanita lebih mendominasi untuk melaksanakan dan memastikan pekerjaan rumah tangga terselesaikan dengan baik.

Stefani, Pudjibudojo dan Prihanto (2000) juga menjelaskan bahwa masyarakat secara umum, para suami maupun diri kaum wanita sendiri beranggapan bahwa peran tradisional sebagai ibu rumah tangga harus terlaksanakan dengan baik meskipun wanita itu sendiri bekerja diluar rumah atau berkarier, akibatnya timbul rasa bersalah pada wanita jika tidak mampu melakukan perannya dengan baik, karena ketika bekerja wanita merasa telah mengabaikan keluarga dan rumah tangganya. Hal ini memungkinkan dukungan sosial suami tidak berkorelasi dengan konflik peran ganda, karena perasaan bersalah tetap ada ketika harus bekerja diluar rumah dan harus meninggalkan tanggung jawab sebagai istri dan ibu rumah tangga, sehingga wanita tetap mengalami konflik peran ganda.

Dari wawancara yang dilakukan peneliti pada 15 Juli 2016 kepada 3 orang guru wanita di Kabupaten Halmahera Barat, mengungkapkan bahwa meskipun mereka telah bekerja sebagai guru, tanggung jawab dalam mengurus rumah dan keluarga tetap menjadi hal yang selalu terpikirkan ketika bekerja. Mereka merasa tidak enak hati kepada suami apabila harus bekerja sampai larut dan tanggung jawab yang seharusnya menjadi milik mereka dikerjakan oleh suami. Selain itu, mereka juga memiliki kekhawatiran akan dipandang oleh lingkungan sekitar sebagai istri atau ibu yang tidak baik karena tidak mampu mengurus rumah tangga yang adalah tanggung jawab utamanya.

Dalam teori kepribadian timur yang dikemukakan oleh Abhidhamma, rasa bersalah juga merupakan salah satu faktor jiwa (internal) yang menyebabkan orang menjadi kaku dan tidak luwes (Ki Fudyartanto, 2003). Faktor internal juga merupakan sumber persoalan wanita yang bekerja sekaligus berperan sebagai istri dan ibu. Ada beberapa wanita yang lebih senang jika dirinya benar-benar hanya menjadi ibu rumah tangga, yang sehari-harinya berkutat di rumah dan mengatur rumah tangga, namun karena keadaan keuangan keluarga, akhirnya wanita dituntut untuk bekerja. Kondisi tersebut mudah menimbulkan stres, karena bekerja tidak murni dari keinginan diri namun seakan menjadi alternatif terakhir untuk membantu ekonomi rumah tangga 
(Jacinta, 2002). Meskipun faktor eksternal dalam hal ini dukungan sosial suami diterima sepenuhnya oleh wanita yang bekerja, namun faktor internal juga sangat menentukan kaum wanita dapat mengalami konflik peran ganda atau tidak.

Beberapa temuan tersebut menjawab persoalan dalam penelitian ini mengenai hubungan negatif yang tidak signifikan antara dukungan sosial suami dengan konflik peran ganda pada guru wanita di Kabupaten Halmahera Barat. Bahwa terdapat faktor-faktor lain seperti pandangan terhadap peran gender, budaya, dan faktor internal.

\section{KESIMPULAN DAN SARAN \\ Kesimpulan}

Berdasarkan hasil penelitian diperoleh kesimpulan sebagai berikut:

1. Dari hasil uji korelasi, menunjukkan bahwa ada hubungan negatif yang tidak signifikan antara dukungan sosial suami dengan konflik peran ganda pada guru wanita (di Kabupaten Halmahera Barat).

2. Dukungan sosial suami sebagian besar ada pada kategori tinggi, sedangkan konflik peran ganda sebagian besar pada kategori sedang.

\section{Saran}

1. Bagi subjek penelitian

Kepada para guru wanita untuk menghindari perasaan bersalah atau penghargaan diri yang rendah ketika melaksanakan pekerjaan, tugas, dan tanggung jawab, karena selain akan mengganggu kinerja sebagai guru, juga akan menganggu lingkungan keluarga. Sebaiknya, lebih terbuka kepada suami atau orang terdekat mengenai pikiran dan perasaan yang membuat rasa bersalah muncul.

2. Bagi peneliti selanjutnya

Diharapkan peneliti selanjutnya lebih memperhatikan faktor-faktor yang mempengaruhi konflik peran ganda, seperti faktor internal, budaya masyarakat, dan pandangan terhadap peran gender.

\section{DAFTAR PUSTAKA}

Ahmad, A. (1997). Work-Family Conflict And Social Suport: A Study Of Female Secretaries In Malaysia. Pertanika J. Soc. Sci. \& Hum, 5(2), 93-101. 
Amazue, L. O. (2013). Impact Of Work And Family Involvement On Work-Family Conflict Of Non Professional Igbo Nigerian Employees. African Journal of Bussiness Management, 7(16), 1515-1521. Doi: 10.5897/AJBM12.1209.

Apollo \& Cahyadi, A. (2012). Konflik Peran Ganda Perempuan Menikah Yang Bekerja Ditinjau Dari Dukungan Sosial Keluarga Dan Penyesuaian Diri. Widya Warta, No. 02, ISSN 08541981

Aycan, Z., \& Eskin. M. (2005). Relative Contributions Of Childcare, Spousal Support, and Organizational Support in ReducingWork-Family Conflict For Men and Women: The Case of Turkey. Sex Roles, Vol. 53, Doi: 10.1007/s11199-005-7134-8.

Azwar, S. (2009). Sikap Manusia, Teori dan Pengukurannya. Jakarta : Pustaka Pelajar.

Badan Pusat Statistik. (2012). Profil perempuan Indonesia. Jakarta: Kementerian Pemberdayaan Perempuan dan Perlindungan Anak Republik Indonesia.

Carlson, D. S., Kacmar, K. M., \& Williams, L. J. (2000). Construction and initial validation of a multidimensional measure of work-family conflict. Journal of Vocational Behavior, 56, 249-276.

Chopur, Z. (2011). Work-Family Conflict: University Employees in Ankara. Hacettepe University, Faculty of Economic and Administrative Sciences, Department of Family and Consumer Sciences.

Far Far, A. R. (2012). Peran gender dalam kehidupan rumah tangga di desa Liang kabupaten Maluku Tengah. Jurnal Agribisnis Kepulauan, 1, 22-24.

Greenhaus, J. H., \& Beutell, N. J. (1985). Sources of conflict between work and family roles. Academy of Management Review, 10(1), 76-88.

Gutek, B. A., Searle, S., \& Klepa, L. (1991). Rational versus gender role explanations for workfamily conflict. Journal of Applied Psychology, 76(4), 560-568.

Jacinta, R.F (2002). Stres Kerja. Diambil dari http://www.baliusada.com/content/view/333/2.

Jex, S. M., \& Bliese, P. D. (1999). Efficacy beliefs as a moderator of the impact of work-related stressors: a multilevel study. Journal of Applied Psychology, Vol. 84, 349-361.

Ki Fudyartanto (2003). Psikologi Kepribadian Timur. Yogyakarta: Pustaka Pelajar.

Murtiningrum, A. (2005). Analisis Pengaruh Konflik Pekerjaan Keluarga Terhadap Stress Kerja Dengan Dukungan Sosial Sebagai Variabel Moderasi (Studi Kasus Pada Guru Kelas 3 SMP Negeri Di Kabupaten Kendal). Tesis. Semarang: Program Studi MM Program Pascasarjana Universitas Diponegoro.

Peeters, M.A.G. \& Rutte, C.G. (2005), Time management behaviour as a moderator for the jobdemand-control interaction. Journal of Occupational Health Psychology, Vol. 10, 64-75. 
Portal Data Indonesia(2014) Guru Berdasarkan Gender. Diambil dari www.data.go.id/dataset/guru-berdasarkan-gender.

Rahmadita, I. (2013). Hubungan antara konflik peran ganda dan dukungan sosial pasangan dengan motivasi kerja pada karyawati di rumah sakit Abdul Rivai-Berau. eJournal Psikologi, 1(1), 58-68.

Riana, A. \& Caroline, D. (2012). 4 Masalah Guru yang Tak Kunjung Selesai. Diambil dari http://edukasi.kompas.com/read/2012/11/26/1337430/4.Masalah.Utama.Guru.yang.Tak. Kunjung.Selesai

Sarafino, E. P. (1994). Health psychology: Biopsychosocial interactions. New York: John Wiley.

Schwarzer, R., \& Knoll, N. (2007). Functional roles of social support within the stress and coping process: A theoretical and empirical overview. International Journal Of Psychology, 42(4), 243-252.

Selvarajan, T. T., Cloninger, A. P., Singh, B. (2013). Social support and work-family conflict: A test of an indirect effects model. Journal of Vocational Behavior, 83, 486-499.

Stefani, Pudjibudojo, K. J, Prihanto, S. X. F. (2000). Hubungan antara peran gender dengan persepsi terhadap dukungan suami dengan fear of success pada wanita karier. Anima: Indonesian Psychological Journal, vol. 16, 51-73.

Wafula, A. N. (2010). Work-Family Conflict Among Women From a Collectivistic Culture. MA minithesis, Department of Industrial Psychology, University of the Western Cape. 